Zeszyty Naukowe Politechniki Częstochowskiej Zarządzanie Nr 22 (2016) s. 33-49

dostępne na: http://www.zim.pcz.pl/znwz

\title{
ZACHOWANIA PRZEDSIĘBIORCZE POLAKÓW I FORMY WSPOMAGANIA ROZWOJU PRZEDSIĘBIORCZOŚCI W POLSCE
}

\author{
Anna Mijal \\ Uniwersytet Opolski \\ Wydział Ekonomiczny
}

\begin{abstract}
Streszczenie: Przemiany społeczno-gospodarcze w Polsce po 1989 roku znalazły odzwierciedlenie w zmianie postaw Polaków związanych z przedsiębiorczością i innowacyjnością. Brak osobistych doświadczeń w tym zakresie i swego rodzaju eksperymentowanie z przedsiębiorczością stały się okazją do uruchomienia różnych form wparcia tego typu aktywności i jej wykorzystania w rozwoju społeczno-gospodarczym regionu i kraju. Skuteczność ich uruchomienia wymaga zbudowania spójnej polityki przedsiębiorczości, innowacyjności i rozwoju podmiotów sektora MŚP, opartej na działaniach administracji publicznej, biznesu, nauki i edukacji.

W opracowaniu wykorzystano analizę wyników międzynarodowego badania Global Entrepreneurship Monitor (GEM), Polskiej Agencji Rozwoju Przedsiębiorczości oraz Stowarzyszenia Organizatorów Ośrodków Innowacji i Przedsiębiorczości w Polsce.

Celem artykułu jest próba diagnozy szeroko rozumianych predyspozycji Polaków w kontekście wzrostu liczby i zakresu form wspomagania ich przedsiębiorczości i innowacyjności.

Słowa kluczowe: rozwój, innowacyjność, przedsiębiorczość, system wsparcia
\end{abstract}

DOI: 10.17512/znpcz.2016.2.03

\section{Wprowadzenie}

Od czasów Richarda Cantillona, uznawanego powszechnie za prekursora pojęć „przedsiębiorca”, ,przedsiębiorstwo”, „przedsiębiorczość”, rzeczone kategorie podlegały wielu interpretacjom, a proces ich tworzenia trudno byłoby nazwać zakończonym. Jeszcze więcej kontrowersji budziły $\mathrm{w}$ zestawieniu $\mathrm{z}$ innowacyjnością, nie tylko w kontekście terminologicznym, ale także w zakresie relacji między tymi kategoriami.

Zamieszanie pojęciowe i brak uzgodnionych definicji podstawowych terminów dotyczy już samej istoty przedsiębiorczości. Sprzyja natomiast upowszechnieniu tzw. prawd obiegowych, a więc pozornie oczywistych tez, których popularność wynika nie tyle z solidnych podstaw empirycznych, ile z faktu, że wszyscy wierzą w ich prawdziwość i traktuja je jako oczywiste. Stąd o krok do prezentowania „genialnie prostych recept" na wszystkie bolączki i problemy, z jakimi borykają się przedsiębiorcy (Cieślik 2014, s. 12).

Przedsiębiorczość jest traktowana jako zjawisko multidyscyplinarne: ekonomiczne, społeczne, z zakresu nauk o zarządzaniu, łączące wykorzystanie szans i majątku (ich posiadanie lub brak) z osobą przedsiębiorcy (model J.A. Timmonsa) (Timmons 1999, s. 176), kładąc nacisk na czerpanie z możliwości, a nie tylko na mobilizację zasobów (Schutte, Barkhuizen 2014, s. 9). 
Transformacja systemu gospodarczego w Polsce stała się szansą dla przedsiębiorców do wykorzystania własnego „uśpionego” potencjału, budując jednocześnie w kolejnych latach jej spektakularny sukces. W dobie realnego socjalizmu sektor prywatny był bądź likwidowany ze względów ideologicznych, bądź tolerowany $\mathrm{w}$ ograniczonym wymiarze, na marginesie dominujacego sektora państwowego (Cieślik 2015, s. 1). W latach osiemdziesiątych XX wieku na popularności zyskało postrzeganie przedsiębiorczości jako procesu tworzenia i budowania czegoś wartościowego praktycznie z niczego, co obrasta licznymi mitami, które są niezwykle trwałe i trudne do przezwyciężenia (Timmons 1999).

Przystąpienie do świata kapitalistycznego tworzyło warunki ułatwiające ściśle związany z przedsiębiorczością proces innowacji, przyspieszając postęp techniczny, a także zwiększając szanse, że dany kraj wykorzysta pojawiające się możliwości. System kapitalistyczny stworzył bowiem wszystkie przełomowe innowacje i był o wiele szybszy w pozostałych aspektach procesu technologicznego - doświadczenie historyczne dostarcza na to niepodważalnych dowodów (Kornai 2010, s. 639). Przemiany systemowe w Polsce po 1989 roku znalazły odzwierciedlenie nie tylko w powstawaniu prywatnych przedsiębiorstw, głównie w sektorze MŚP, ale także w zmianie podejścia do ich postrzegania i oceny własnych możliwości przez aspirujących i aktywnych przedsiębiorców.

Prawdziwy renesans przedsiębiorczości i sposobu jej postrzegania w Polsce dokonał się zasadniczo na przełomie XX i XXI wieku dzięki aktywności małych, początkujących firm i ich właścicieli, którzy wdrażając przełomowe innowacje byli w stanie podważyć dominację wielkich koncernów w ważnych gałęziach gospodarki (Cieślik 2014, s. 139).

\section{Rola przedsiębiorcy w procesie przedsiębiorczości}

W literaturze przedmiotu wyróżnia się wiele kategorii przedsiębiorców, których cechy stają się podstawą tworzenia wielu definicji przedsiębiorczości i pojęć pokrewnych. W tym kontekście R. Smilor wymienia trzy zasadnicze ich typy: przedsiębiorców aspirujących (zainteresowanych powołaniem własnego przedsiębiorstwa w przyszłości), uznających przedsiębiorczość za styl życia (zarabiających na siebie) oraz przedsiębiorców wzrostu (właścicieli dynamicznie rozwijających się przedsiębiorstw, tworzących nowe miejsca pracy) (Smilor 2001). Model procesu przedsiębiorczości według J.A. Timmonsa, oparty na wykorzystaniu potencjału przedsiębiorcy, przedstawiono na Rysunku 1 . W tym podejściu przedsiębiorczość to pogoń za okazjami bez uwzględnienia ograniczeń stwarzanych przez aktualnie posiadane lub kontrolowane zasoby (Timmons 1999, s. 329). Autor akcentuje $\mathrm{w}$ ten sposób znaczenie zdolności przedsiębiorcy, dysponującego atrakcyjnym pomysłem o wysokim potencjale rozwojowym, do przyciągnięcia uwagi inwestorów (Glinka, Gudkova 2011, s. 19). Przedsiębiorczość stanowi zatem rezultat wzajemnej interakcji ludzi (zespół), szans rynkowych i zasobów. 


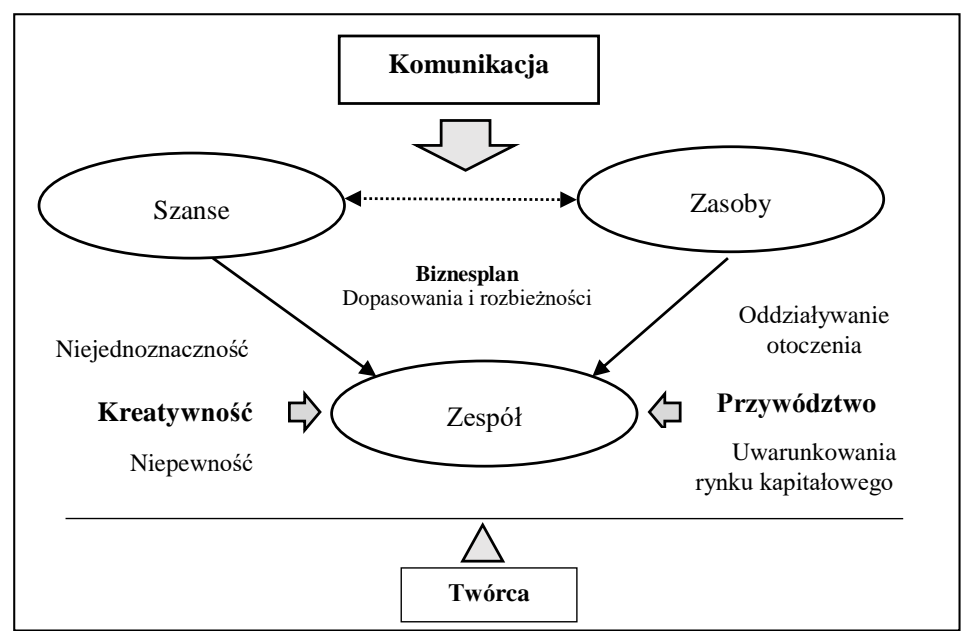

Rysunek 1. Model procesu przedsiebiorczości według J.A. Timmonsa

Źródło: Opracowanie własne na podstawie: (Timmons 1999)

Model J.A. Timmonsa można rozbudować, wykorzystując koncepcję przedsiębiorczości S. Shane'a i S. Venkataramana, która opiera się na następujących założeniach (Shane 2003, s. 5):

- Przedsiębiorczość wymaga istnienia szans rynkowych. Zawierają one komponent obiektywny, który sprawia, że nie istnieją one wyłącznie w świadomości przedsiębiorców.

- Przedsiębiorczość zakłada występowanie różnic pomiędzy osobami, które powodują odmienne możliwości dostrzegania przez osoby szans rynkowych.

- Ponoszenie ryzyka jest nieodłączną częścią procesu przedsiębiorczego, co wiąże się z tym, że szanse rynkowe $\mathrm{z}$ natury są niepewne; proces przedsiębiorczy wymaga organizowania rozumianego nie w sensie założenia nowego przedsięwzięcia biznesowego, lecz tworzenia nowych kombinacji zasobów.

- Proces przedsiębiorczy wymaga wprowadzania innowacji, przy czym nie muszą one mieć charakteru przełomowego.

Światowe wyniki badań w zakresie przedsiębiorczości (np. European Union Labour Force Survey, Global Entrepreneurship Monitor ${ }^{1}$ ) wskazują, że Polacy pozytywnie postrzegają swoje zdolności przedsiębiorcze. Prawie $55 \%$ dorosłych mieszkańców Polski twierdziło (dane z 2013 roku), że jest dobrze przygotowanych

${ }^{1}$ Global Entrepreneurship Monitor (GEM) to największy międzynarodowy projekt badania przedsiębiorczości. W 2014 roku badaniem objetto 73 kraje świata, które reprezentuja ponad $72 \%$ populacji świata i 90\% globalnego PKB. Uczestniczyło w nich 206 tys. dorosłych osób oraz około 4 tys. ekspertów z dziedziny przedsiębiorczości. Badania GEM w Polsce są prowadzone przez PARP i UE w Katowicach od 2011 roku. 
do prowadzenia działalności gospodarczej. Jest to wynik o ponad 10 punktów procentowych wyższy niż średnio $\mathrm{w}$ UE oraz $\mathrm{w}$ krajach zorientowanych na innowacje (Rysunek 4). Niestety, pomimo przekonania o wysokich umiejętnościach przedsiębiorczych Polacy nisko oceniają dostępność szans na rozpoczęcie dzialalności (Łapiński, Nieć, Rzeźnik, Węcławska 2015, s. 45).

Wybrane wskaźniki przedsiębiorczości w Polsce i w UE (średnia) w latach 2011-2014 według danych Global Entrepreneurship Monitor (GEM) przedstawiono w Tabeli 1.

Tabela 1. Wybrane wskaźniki przedsiębiorczości w Polsce i UE w latach 2011-2014 [\%]

\begin{tabular}{|c|c|c|c|c|c|c|}
\hline Wskaźniki & $\begin{array}{c}\text { Polska } \\
2011\end{array}$ & $\begin{array}{c}\text { Polska } \\
2012\end{array}$ & $\begin{array}{c}\text { Polska } \\
2013\end{array}$ & $\begin{array}{c}\text { Polska } \\
2014\end{array}$ & $\begin{array}{c}\text { UE } \\
\text { (średnia)* } \\
2013\end{array}$ & $\begin{array}{c}\text { UE } \\
\text { (średnia)* } \\
2014\end{array}$ \\
\hline $\begin{array}{c}\text { Intencje przedsiębiorcze - plany } \\
\text { założenia firmy w ciągu } 3 \text { lat (pro- } \\
\text { cent dorosłych niepodejmujących } \\
\text { działań w kierunku założenia firmy) }\end{array}$ & 23 & 24,2 & 17,3 & 15,6 & 13,5 & 12,1 \\
\hline $\begin{array}{l}\text { Rozpoznawanie szansy } \\
\text { (procent dorosłych osób) }\end{array}$ & 33,1 & 20,4 & 26,1 & 31,3 & 28,7 & 34,8 \\
\hline $\begin{array}{l}\text { Zdolności przedsiębiorcze } \\
\text { (procent dorosłych osób) }\end{array}$ & 52,0 & 53,9 & 51,8 & 54,3 & 42,3 & 42,3 \\
\hline $\begin{array}{l}\text { Strach przed porażką (procent doro- } \\
\text { słych osób dostrzegających dobrą } \\
\text { okazję do założenia firmy) }\end{array}$ & 54,1 & 58,7 & 46,7 & 51,1 & 39,8 & 40,7 \\
\hline $\begin{array}{l}\text { Przedsiębiorczość jako dobra ścież- } \\
\text { ka kariery (procent dorosłych osób) }\end{array}$ & 73 & 67,9 & 66,8 & 63,3 & 56,9 & 56,9 \\
\hline $\begin{array}{l}\text { Wysoki status przedsiębiorcy (pro- } \\
\text { cent dorosłych osób) }\end{array}$ & 64,4 & 57,1 & 59,9 & 56,5 & 65,5 & 66,6 \\
\hline $\begin{array}{c}\text { Pozytywny wizerunek przedsiębior- } \\
\text { czości w mediach (procent doro- } \\
\text { słych osób) }\end{array}$ & 58,0 & 56,3 & 58,5 & 54,5 & 49,0 & 53,3 \\
\hline $\begin{array}{c}\text { TEA** } \\
\text { (procent dorosłych osób) }\end{array}$ & 9,0 & 9,4 & 9,3 & 9,2 & 8,0 & 7,8 \\
\hline $\begin{array}{c}\text { Dojrzałe firmy } \\
\text { (procent dorosłych osób) }\end{array}$ & 5,0 & 5,8 & 6,5 & 7,3 & 6,4 & 6,7 \\
\hline $\begin{array}{l}\text { Zaprzestanie działalności } \\
\text { (procent dorosłych osób) }\end{array}$ & 4,2 & 3,9 & 4,0 & 4,2 & 2,9 & 2,6 \\
\hline $\begin{array}{c}\text { Przedsiębiorczość z konieczności } \\
\text { (procent dorosłych osób) }\end{array}$ & 47,6 & 40,7 & 47,4 & 36,8 & 22,7 & 22,8 \\
\hline $\begin{array}{l}\text { Przedsiębiorczość z powodu do- } \\
\text { strzeżenia szansy poprawy standardu } \\
\text { życia (procent dorosłych osób) }\end{array}$ & 31,5 & 30,1 & 32,7 & 47,1 & 47,0 & 47,9 \\
\hline
\end{tabular}

*Dane dotyczą 23 krajów UE, które zostały objęte badaniem w 2013 i w 2014 roku.

** Wskaźnik w GEM o charakterze prognostycznym w zakresie aktywności przedsiębiorczej. Obejmuje preprzedsiębiorców (firmy działające nie dłużej niż 3 miesiące) oraz nowe firmy, czyli obecne na rynku do 3,5 roku.

Źródło: Opracowanie własne na podstawie: (Bosma, Wennekers, Amorós 2012; Polska 2013... 2014, s. 11; SingerAmorós, Moska Arreola 2015) 
Wyniki badania GEM wskazują na rosnący udział dorosłych Polaków podejmujących działania w kierunku założenia firmy i rosnący udział (z wyjątkiem danych z 2012 roku) respondentów rozpoznających rynkowe szanse (około 31\% dorosłych osób w 2014 roku). Ponad 63\% badanych osób (tendencja spadkowa) uznało w 2014 roku przedsiębiorczość jako dobra ścieżkę kariery, a pozytywny wizerunek przedsiębiorczości w mediach dostrzega ponad 54\% dorosłych osób. Wielu przedsiębiorców zauważa $\mathrm{w}$ działaniach przedsiębiorczych dobrą okazję oraz możliwość poprawy standardu życia.

Współczesnym rozważaniom nad przedsiębiorczością towarzyszy jej charakterystyczny wymiar - innowacyjność. Przedsiębiorczość, rozumiana jako działalność gospodarcza, może stanowić szerokie jej znaczenie, a przedsiębiorczość innowacyjna to przedsiębiorczość w wąskim znaczeniu (Targalski 2006, s. 7). Przedsiębiorczość i innowacyjność można traktować jako odrębne, choć współzależne czynniki rozwoju przedsiębiorstw i gospodarki jako całości (Cieślik 2014, s. 32; Baumol 2010). Zgodnie z regułami przyjętymi w Unii Europejskiej jednym z najważniejszych kryteriów uznania danego rozwiązania za innowacyjne jest jego wdrożenie i zastosowanie w praktyce gospodarczej. Innowacja zatem, by nią zostać, musi mieć charakter utylitarny (Wierżyński 2015). To właśnie przedsiębiorczość powiązaną z innowacyjnością uznano za siłę napędową modernizacji, strukturalnej odnowy i wzrostu gospodarki (Matusiak 2010, s. 87-88). Fazy rozwoju gospodarczego w badaniu Global Entrepreneurship Monitor (GEM) przedstawiono na Rysunku 2.

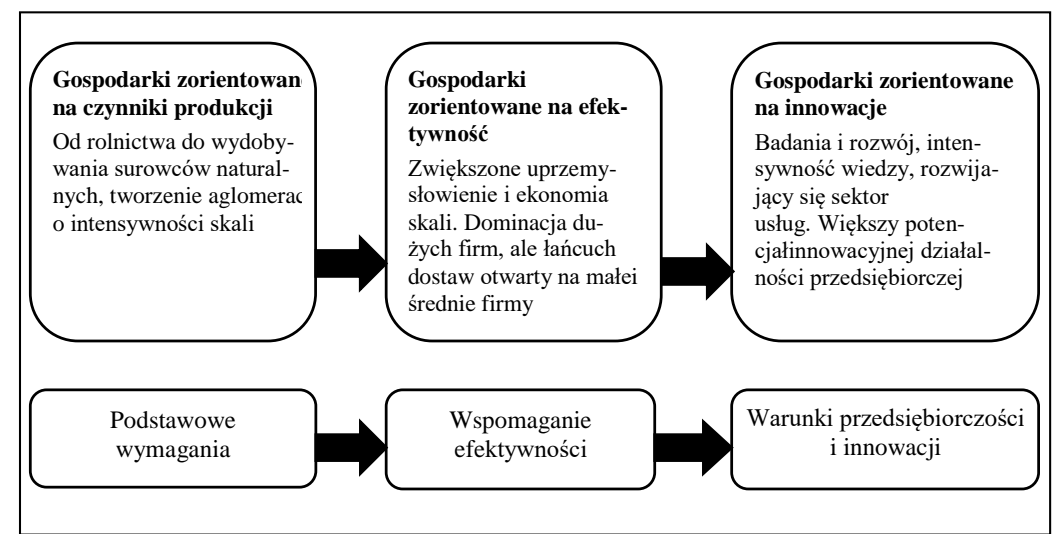

Rysunek 2. Fazy rozwoju gospodarczego (badanie GEM)

Źródło: (Bosma, Wennekers, Amoros 2012, s. 13)

Uwarunkowania makrootoczenia, sprzyjające decyzjom prorozwojowym przedsiębiorców, mogą stać się impulsem do innowacyjnego „skoku”. Niezbędne są jednak zmiany o charakterze strukturalnym, pozwalające na kreowanie nowych rozwiązań i dyfuzję tych sprawdzonych (zob. Hernik 2015). 
W każdej z trzech faz rozwoju gospodarczego zasadniczo odmienna jest rola państwa we wspieraniu przedsiębiorczości i wzrostu gospodarczego. W gospodarkach zorientowanych na czynniki produkcji rola ta jest najbardziej istotna $\mathrm{w}$ rozwoju instytucji, infrastruktury stabilności makroekonomicznej oraz zdrowia i podstawowej edukacji. W gospodarkach zorientowanych na efektywność państwo powinno poprawiać funkcjonowanie rynków kapitałowych oraz pracy, przyciągać więcej inwestycji zagranicznych i tworzyć systemy edukacyjne zdolne do kształcenia ludzi w kierunku adaptowania technologii. W gospodarkach zorientowanych na innowacje kluczowa rola państwa tkwi w tworzeniu i komercjalizacji wiedzy (Zbierowski i in. 2012, s. 12).

W literaturze przedmiotu coraz częściej wskazuje się jednocześnie na zmianę paradygmatu innowacji. Wykorzystanie wewnętrznego potencjału przedsiębiorstwa (innowacje zamknięte) przybiera coraz częściej formę wymiany wiedzy i nowych rozwiązań pomiędzy przedsiębiorstwem a jego otoczeniem (innowacje otwarte) (Kozarkiewicz 2010, s. 20-21). Polska w badaniach GEM zaliczana jest do grupy gospodarek zorientowanych na efektywność, w okresie przejściowym dochodzenia do systemu gospodarczego o charakterze innowacji otwartych.

\section{Wspomaganie zachowań przedsiębiorczych w polityce gospodarczej}

Przedsiębiorczość, zwłaszcza o charakterze innowacyjnym, wymaga i oczekuje, przede wszystkim ze względu na duże zaległości w tym zakresie, pewnych form pomocy, głównie w odniesieniu do sektora małych i średnich przedsiębiorstw, nie jako najsłabszego obszaru aktywności przedsiębiorców, ale podkreślając niewykorzystany często potencjał elastyczności tego typu podmiotów. Wprowadzanie metod przedsiębiorczego działania dotyczy także sfer poza gospodarką: uczelni (przedsiębiorczość akademicka), organizacji społecznych nienastawionych na zysk (przedsiębiorczość społeczna), sfery kultury i sztuki (przedsiębiorczość w sektorach kreatywnych), a nawet administracji państwowej i samorządowej (przedsiębiorczość publiczna) (Cieślik 2014, s. 23), zarówno w zakresie własnej działalności, jak i wsparcia innych jednostek.

Działania interwencyjne, o prorozwojowym charakterze, podejmowane w ramach polityki ekonomicznej i społecznej kraju tworzą, a właściwie powinny tworzyć system wsparcia zarówno w odniesieniu do instytucji, jak i merytorycznego zakresu ich działalności. W polskich realiach raczej trudno mówić o systemie wspierania innowacyjności i przedsiębiorczości, a przynajmniej jak dotąd nie prezentowano podejmowanych działań jako systemu. Były to zabiegi finansowane głównie ze środków europejskich w szeroki sposób obejmujące przedsiębiorczość i innowacyjność - mające charakter odrębnych programów, opartych na stosowaniu kryteriów ograniczających podmiotom gospodarczym dostęp do środków pomocowych (Mażewska 2015, s. 9). Współpraca przedsiębiorców z otoczeniem nie oznacza jednak tworzenia preferencyjnych warunków dla określonej, wybranej grupy beneficjentów, ale wypracowanie atrakcyjnego klimatu inwestycyjnego i poprawę warunków życia społeczności. 
Relacje przedsiębiorców z jednostkami naukowymi i środowiskiem akademickim owocują różnymi formami powiązań instytucjonalnych lub osobowych, o formalnym i nieformalnym charakterze. Efektywna działalność ośrodków innowacji wymaga także partnerstwa i sieciowej współpracy z administracją publiczną (Rysunek 3).

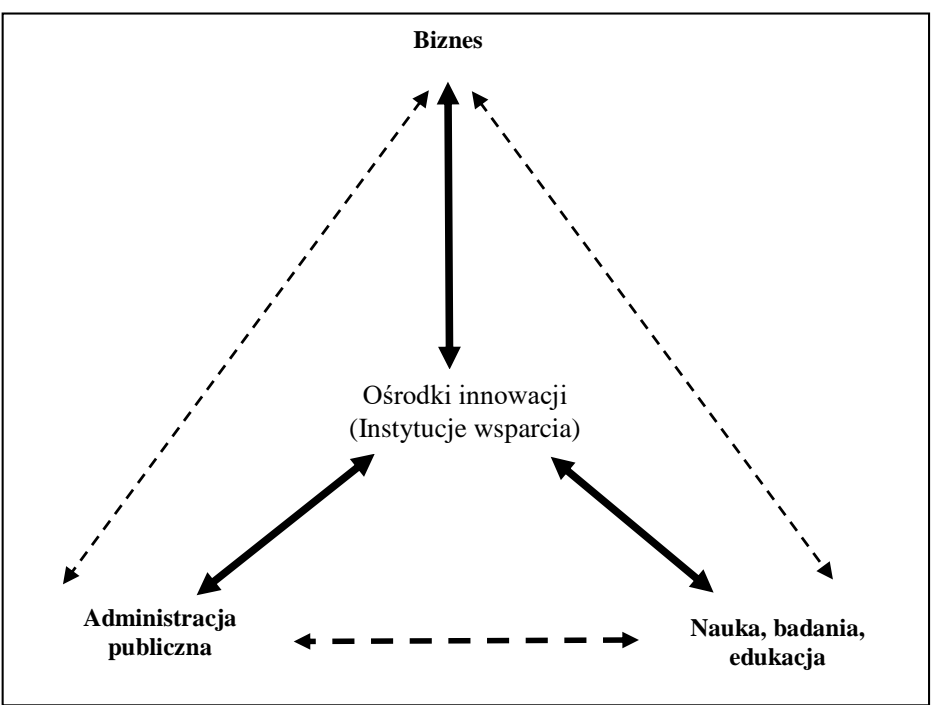

\section{Rysunek 3. Partnerstwo dla rozwoju w gospodarce wiedzy}

Źródło: (Matusiak 2010, s. 211)

Funkcjonalnie system ten krystalizuje się na poziomie instrumentów bazowych polityki horyzontalnej (innowacyjnej, przedsiębiorczości i MŚP) oraz pozostałych rodzajów polityki (regionalnej, naukowo-badawczej, przemysłowej, rolnej, rynku pracy, edukacyjnej), zawierających komponenty w zakresie innowacyjności i przedsiębiorczości (Matusiak 2010, s. 12).

Doświadczenia różnych państw i regionów, wynikające także z poziomu rozwoju gospodarczego, wskazują, że nie ma jednego, uniwersalnego modelu takiego systemu, a jego struktura i zakres zadaniowy wynikają z (Matusiak 2010, s. 13):

1. opracowanej strategii rozwoju ekonomiczno-społecznego i przestrzennego oraz zawartych w niej priorytetów, celów, zadań oraz środków ich osiągania na poziomie krajowym, regionalnym i lokalnym, a w przypadku państw europejskich również unijnym;

2. stosowanych instrumentów regulacyjnych wyrastających ze stanowienia prawa i przepisów administracyjnych (np. własność intelektualna, koncesje, wymogi rejestrowe itp.) oraz realizowanej polityki makroekonomicznej (np. ulgi i zwolnienia podatkowe, subwencje); 
3. realizowanych programów wsparcia będących selektywną instrumentalizacją polityki realizowanej przez rząd, regiony i samorządy lokalne (Komisja Europejska);

4. charakteru i intensywności działania instytucji wsparcia realizujących programy na poziomie krajowym, regionalnym i lokalnym.

W efekcie można mówić o jakościowo nowym, dynamicznym i innowacyjnym obliczu przedsiębiorczości na przełomie XX i XXI wieku (Cieślik 2010, s. 19), chociaż uwarunkowania jej rozwoju w Polsce, poddawane ocenie nawet w 2013 roku, wciąż nie należą do wzorcowych i oczekiwanych. Podstawową przyczyną takiego stanu rzeczy są, zdaniem ekspertów, niedostatki w zakresie kształtowania postaw przedsiębiorczych i nauczania przedsiębiorczości na wszystkich poziomach edukacji. Na to nakładają się uwarunkowania społeczno-kulturowe, które nie zachęcają do kreatywności i innowacyjności (Polska 2013... 2014, s. 11). W statystyce publicznej oraz $\mathrm{w}$ badaniach naukowych stosowane są różnorodne metody pomiaru aktywności przedsiębiorczej, najczęściej w cyklu rocznym, co zaspakaja podstawowe potrzeby związane z prowadzeniem długofalowej polityki gospodarczej, wobec sektora przedsiębiorczości. Brak jest natomiast narzędzi do pomiaru krótkookresowych (miesiąc, kwartał) zmian, czyli „koniunktury przedsiębiorczej”. Istotną przeszkodą jest brak danych ilustrujących tego typu krótkookresowe zmiany lub wysokie koszty i obciążenia natury administracyjnej (Cieślik, Łopaciński 2014, s. 9).

Zdaniem P. Druckera bycie „prawdziwym” przedsiębiorcą zapewnia właśnie innowacyjność; a tylko takie przedsiębiorstwo, które jest oparte na celowej innowacji, można uznać za systematycznie przedsiębiorcze (Drucker 1992, s. 35-38). Innowacja stanowi zatem kwintesencję przedsiębiorczości (Kwiatkowski 2000, s. 82).

Pomoc publiczna jest przesuwana $\mathrm{z}$ określonych podmiotów czy branż znajdujących się w trudnej sytuacji i wymagających interwencji na rzecz aktywizacji czynników prorozwojowych, takich jak kreatywność, innowacyjność i przedsiębiorczość (Matusiak 2006, s. 140-141). Firmy z tego sektora, w przeciwieństwie do dużych przedsiębiorstw, najczęściej nie posiadają żadnej strategii umiędzynarodowienia, co niewątpliwie potwierdza potrzebę wsparcia tych działań ze strony publicznej (Wach 2015, s. 82).

Od poczatku transformacji systemowej zwracano uwage na wsparcie instytucjonalne indywidualnej i korporacyjnej przedsiębiorczości, co z kolei przełożyło się na okresowe zmiany liczby ośrodków innowacji i przedsiębiorczości, wynikajace z zapotrzebowania na ich usługi oraz uwarunkowań, jakie tworzyły - w ostatnich 15 latach - fundusze europejskie będące ich głównym źródłem zasilania finansowego (Mażewska 2015, s. 10). W ten sposób w strukturze podmiotów systemu gospodarczego, w ramach obowiązującego systemu prawnego i kulturowego, pojawiły się organizacje świadczące usługi proinnowacyjne poprzez powiązanie polityki innowacyjnej, polityki przedsiębiorczości i polityki wsparcia MŚP (Rysunek 4). 


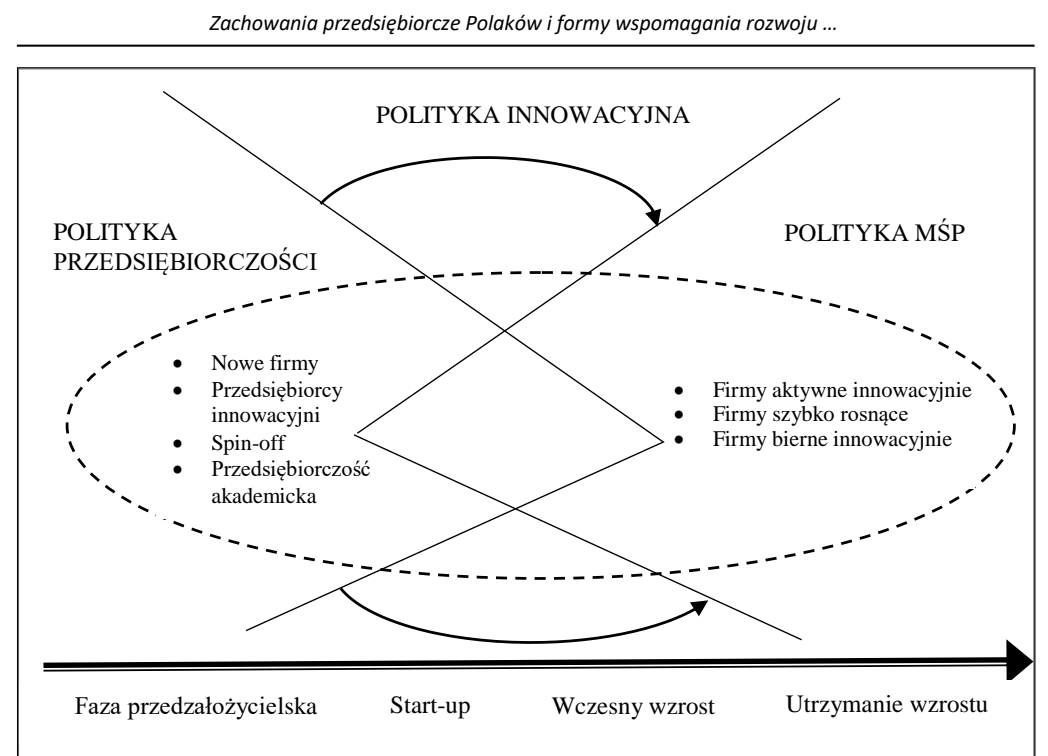

Rysunek 4. Powiązania polityki innowacyjnej, polityki przedsiębiorczości i polityki wsparcia MŚP

Źródło: (Stawasz 2011, s. 48)

Różne formy wsparcia merytorycznego i finansowego przedsiębiorczych i innowacyjnych jednostek określa się mianem ośrodków innowacji i przedsiębiorczości (OIiP). Ośrodki te są wykonawczym ogniwem programów wsparcia. Z ich pomocy korzystają osoby i podmioty rozpoczynające działalność gospodarczą, niezdolne ze względów finansowych lub merytorycznych do sięgnięcia po komercyjną ofertę rynkową. Ich aktywność ma wywoływać impulsy rozwojowe szczególnie w perspektywie lokalnej i regionalnej (Matusiak, Mażewska, Banisch 2011, s. 35-36).

Publiczne subwencjonowanie innowacji może być skuteczne, ale jednocześnie pociąga za sobą wiele zagrożeń, prowadząc do wykrzywienia bodźców dla firm: ich innowacyjność może się przeradzać w wynajdywanie nowych sposobów „wyszarpywania" środków publicznych (rent-seeking) lub być traktowana jako forma tworzenia warunków nieuczciwej konkurencji (Matusiak (red.) 2011, s. 12).

Ośrodki Innowacji i Przedsiębiorczości stanowią instytucje wsparcia o charakterze usługowym, zarówno dla sektora publicznego, jak i prywatnego. Ich pojawienie się związane jest $\mathrm{z}$ początkiem lat dziewięćdziesiątych $\mathrm{XX}$ wieku (Mażewska 2015, s. 7). Mimo różnych form prawno-organizacyjnych prowadzonej działalności posiadają one charakter niekomercyjny (non-profit), a ewentualne nadwyżki muszą przeznaczać na cele statutowe, tzn. związane ze wspieraniem rozwoju przedsiębiorczości i innowacyjności. Przeprowadzone oceny potrzeb in- 
stytucji proinnowacyjnych wskazywały przede wszystkim na konieczność podniesienia poziomu profesjonalizacji ich działalności, gdyż tylko kompetentne i dobrze przygotowane zaplecze instytucjonalne może efektywnie wspierać innowacyjną przedsiębiorczość oraz procesy transferu technologii i komercjalizacji wiedzy (Matusiak, Mażewska, Banisch 2011, s. 33).

\section{Diagnoza stanu i struktury instytucji wspierania przedsiębiorczości w Polsce w latach 1990-2014}

Proces tworzenia zasobów wiedzy i ich przekształcania w innowacje jest zdeterminowany zdolnością do współdziałania wielu podmiotów. Innowacyjne przedsiębiorstwa potrzebują dla swojego rozwoju lokalnego otoczenia generującego sieć współpracy i partnerstwa (Matusiak, Mażewska, Banisch 2011, s. 10). Na Rysunku 5 przedstawiono obszary systemu komercjalizacji wiedzy, stanowiące elementy inicjatywy PARP tworzenia skutecznego otoczenia innowacyjnego biznesu.

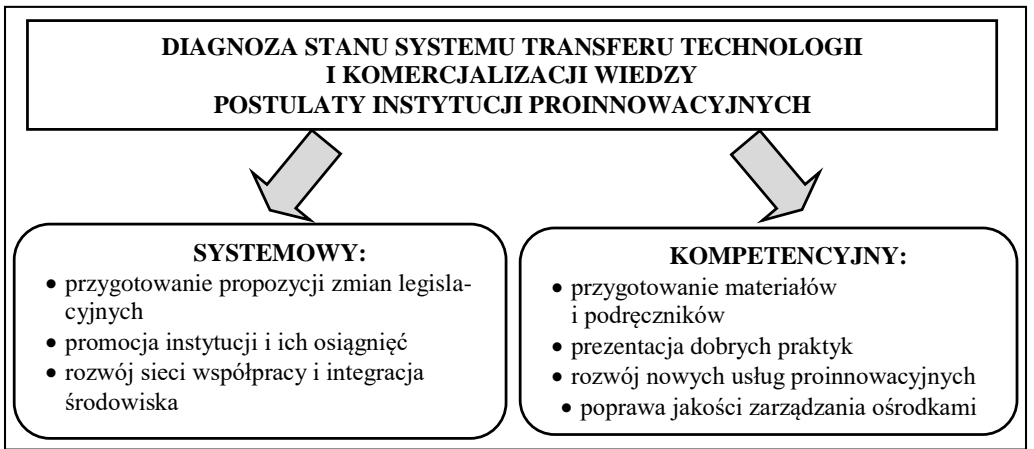

Rysunek 5. Obszary oddziaływania Inicjatywy Skuteczne Otoczenie Innowacyjnego Biznesu PARP

Źródło: (Matusiak, Mażewska, Banisch 2011, s. 13)

Różnorodność podejmowanych zadań, docelowe grupy odbiorców usług, czy też potrzebne kompetencje kadr, stały się kryteriami klasyfikacji instytucji wsparcia, wyróżniając w każdej z tych grup określone ich kategorie, charakteryzujące się specyficzną misją, szczegółowymi celami działania oraz strukturą, sposobem i zakresem funkcjonowania (Matusiak 2006; Mażewska, Bąkowski 2015, s. 11):

1. ośrodki przedsiębiorczości - szeroka promocja i inkubacja przedsiębiorczości (często w grupach dyskryminowanych), dostarczanie usług wsparcia do małych firm i aktywizacja rozwoju regionów peryferyjnych lub dotkniętych kryzysem strukturalnym 
2. ośrodki innowacji - szeroka promocja i inkubacja innowacyjnej przedsiębiorczości, transfer technologii i dostarczanie usług proinnowacyjnych, aktywizacja przedsiębiorczości akademickiej i współpracy nauki z biznesem;

3. instytucje finansowe - ułatwienie dostępu dofinansowania działalności nowo powstałych oraz małych firm bez historii kredytowej, dostarczanie usług finansowych dostosowanych do specyfiki innowacyjnych przedsięwzięć gospodarczych.

W roku 2012 dokonano weryfikacji stanu instytucji wsparcia, wskazując ich określone kategorie w każdej z trzech podstawowych grup (Mażewska, Bąkowski 2015, s. 12):

- ośrodki przedsiębiorczości: ośrodki szkoleniowo-doradcze, ośrodki przedsiębiorczości, centra biznesu, kluby przedsiębiorczości, punkty konsultacyjne, punkty konsultacyjno-doradcze, preinkubatory, inkubatory przedsiębiorczości;

- ośrodki innowacji: centra transferu technologii, akademickie inkubatory przedsiębiorczości, inkubatory technologiczne, e-inkubatory, parki technologiczne, naukowo-badawcze, przemysłowo-technologiczne, technopole;

- instytucje finansowe: regionalne i lokalne fundusze pożyczkowe, fundusze poręczeń kredytowych, fundusze kapitału zalążkowego, sieci aniołów biznesu.

Podział ośrodków innowacji i przedsiębiorczości (OIiP) zawsze odnosił się do ich rzeczywistych obszarów działania. W 2014 roku wypracowana została nowa kategoryzacja ośrodków, uwzględniająca tzw. centra innowacji (Tabela 2). W zmodyfikowanej klasyfikacji zachowany został jednak ich podział na trzy grupy ośrodków, dość jednoznacznie identyfikowalne pod względem specyfiki i zakresu działania: ośrodki przedsiębiorczości, ośrodki innowacji oraz pozabankowe instytucje finansowe (Mażewska 2015, s. 7).

Tabela 2. Klasyfikacja ośrodków innowacji i przedsiębiorczości w 2014 roku

\begin{tabular}{|c|c|c|}
\hline \multicolumn{3}{|c|}{ Ośrodki innowacji i przedsiębiorczości } \\
\hline Ośrodki przedsiębiorczości & Ośrodki innowacji & $\begin{array}{l}\text { Pozabankowe instytucje } \\
\text { finansowe }\end{array}$ \\
\hline $\begin{array}{l}\text { Ośrodki szkoleniowo- } \\
\text {-doradcze } \\
\text { Ośrodki przedsiębiorczości } \\
\text { Centra biznesu } \\
\text { Preinkubatory } \\
\text { Inkubatory przedsiębiorczości }\end{array}$ & $\begin{array}{l}\text { Parki technologiczne, naukowe, nau- } \\
\text { kowo-technologiczne, przemysłowo- } \\
\text {-technologiczne, techno-parki } \\
\text { Inkubatory technologiczne } \\
\text { Centra transferu technologii } \\
\text { Akademickie inkubatory } \\
\text { przedsiębiorczości } \\
\text { Centra innowacji }\end{array}$ & $\begin{array}{l}\text { Regionalne i lokalne fundu- } \\
\text { sze pożyczkowe } \\
\text { Fundusze poręczeń } \\
\text { kredytowych } \\
\text { Fundusze kapitału } \\
\text { zalążkowego } \\
\text { Sieci aniołów biznesu }\end{array}$ \\
\hline
\end{tabular}

Źródło: (Mażewska 2015, s. 8)

Cechą charakterystyczną instytucji wsparcia jest ich działalność nienastawiona na osiąganie zysku, również w przypadku instytucji korzystających z formy prawnej opartej na kodeksie handlowym (Mażewska, Bąkowski 2015, s. 12). Praktyka funkcjonowania OIiP wskazuje, że ich działalność może być realizowana przy wykorzystaniu następujących form prawnych (Matusiak (red.) 2011, s. 127): 
- fundacji i stowarzyszeń lub jednostek przez nie powołanych, które realizują programy rozwoju przedsiębiorczości i transferu technologii oraz działające na rzecz rozwoju lokalnego;

- spółek prawa handlowego (prywatne, publiczne, publiczno-prywatne) zgodnie z dokumentami organizacyjno-rejestrowymi działajace non-for--profit, podejmujące działania prorozwojowe lub działające na rzecz rozwoju gospodarki opartej na innowacjach i wiedzy, które nie są nastawione na maksymalizację zysków oraz jego podział między poszczególnych udziałowców;

- izb gospodarczych, organizacji rzemiosła, zrzeszeń i związków pracodawców oraz inne instytucje przedstawicielskie biznesu, które podejmują inicjatywy i działania prorozwojowe;

- wyodrebnionych organizacyjnie i finansowo jednostek samorządowych, administracji publicznej i jednostek naukowych, które zorientowane są na wspieranie rozwoju lokalnej gospodarki.

Od początku transformacji systemowej w 1990 roku liczba ośrodków innowacji i przedsiębiorczości w Polsce systematycznie rosła (poza okresem 1998-2000), osiągając w 2011 roku liczbę 738 oraz 821 w roku 2012. Kolejne lata przyniosły jednak stopniowe zmniejszanie ich liczebności, aż do $681 \mathrm{w}$ roku 2014 (Rysunek 6), co oznacza prawie 16-procentowy spadek ich liczby w 2014 roku w stosunku do danych z roku bezpośrednio poprzedzającego.

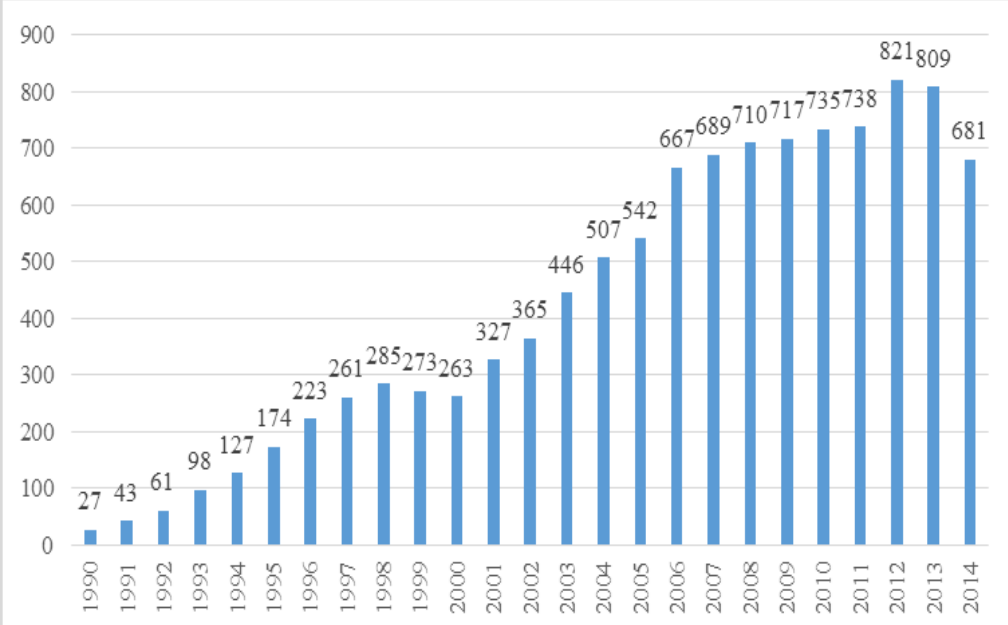

Rysunek 6. Rozwój ośrodków innowacji i przedsiębiorczości w Polsce w latach 1990-2014

Źródło: (Mażewska 2015, s. 17) 
Ze względu na swoją specyfikę i społeczne podłoże ich powstania są one ważnym elementem wypełniającym lukę między mechanizmami rynkowymi a działaniami administracji publicznej. Spełniają na rynku funkcje usługowe, tworząc specyficzną sieciową infrastrukturę instytucjonalną, umożliwiającą przedsiębiorcom dynamizację procesów rozwojowych oraz realizację wyznaczonych strategii (Mażewska 2015, s. 8).

Spośród ogółu podmiotów wsparcia przedsiębiorczości w 2014 roku identyfikuje się w Polsce łącznie 176 aktywnych ośrodków innowacji i inkubatorów przedsiębiorczości (w ramach 137 instytucji prowadzących), co oznacza ponad 13-procentowy spadek w stosunku do stanu z 2012 roku (Tabela 3).

Tabela 3. Rozwój ilościowy poszczególnych typów ośrodków innowacji i przedsiębiorczości w latach 1995-2014

\begin{tabular}{|c|c|c|c|c|c|c|c|c|c|c|}
\hline Wyszczególnienie & 1995 & 1997 & 1999 & 2000 & 2004 & 2007 & 2009 & 2010 & 2012 & 2014 \\
\hline $\begin{array}{l}\text { Parki technologiczne } \\
\text { Inicjatywy parkowe }\end{array}$ & 1 & 1 & 3 & 3 & 12 & 15 & $\begin{array}{l}23 \\
23\end{array}$ & $\begin{array}{l}24 \\
21\end{array}$ & $\begin{array}{l}40 \\
14\end{array}$ & $\begin{array}{c}42 \\
0\end{array}$ \\
\hline $\begin{array}{c}\text { Inkubatory technologiczne } \\
\text { Inkubatory } \\
\text { przedsiębiorczości }\end{array}$ & 4 & 5 & 49 & 44 & 53 & $\begin{array}{l}16 \\
47\end{array}$ & $\begin{array}{l}17 \\
46\end{array}$ & 20 & $\begin{array}{l}29 \\
58\end{array}$ & $\begin{array}{l}24 \\
46\end{array}$ \\
\hline $\begin{array}{l}\text { Akademickie inkubatory } \\
\text { przedsiębiorczości }\end{array}$ & $*$ & * & $*$ & $*$ & * & 49 & 51 & 62 & 73 & 24 \\
\hline $\begin{array}{c}\text { Centra transferu } \\
\text { technologii }\end{array}$ & 1 & 5 & 23 & 20 & 39 & 87 & 87 & 90 & 69 & 42 \\
\hline Centra innowacji & $*$ & $*$ & $*$ & $*$ & $*$ & $*$ & $*$ & $*$ & $*$ & 47 \\
\hline $\begin{array}{l}\text { Fundusze kapitału } \\
\text { zalążkowego }\end{array}$ & $*$ & * & $*$ & * & * & 6 & 9 & 12 & 68 & 103 \\
\hline Sieci aniołów biznesu & $*$ & $*$ & $*$ & $*$ & $*$ & $*$ & 7 & 8 & 10 & 7 \\
\hline $\begin{array}{c}\text { Fundusze pożyczkowe } \\
\text { Fundusze poręczeń } \\
\text { kredytowych }\end{array}$ & & 48 & 51 & 24 & 76 & 84 & 82 & 82 & 86 & 81 \\
\hline $\begin{array}{c}\text { Ośrodki } \\
\text { szkoleniowo-doradcze }\end{array}$ & & 153 & 147 & 142 & 280 & 326 & 318 & 317 & 319 & 207 \\
\hline ŁĄCZNIE & 174 & 261 & 273 & 266 & 507 & 694 & 711 & 735 & 821 & 681 \\
\hline
\end{tabular}

Źródło: (Mażewska 2015, s. 17)

Analiza danych zawartych w Tabeli 3 pozwala zauważyć istotne zmiany w zakresie stanu i struktury ośrodków innowacji i przedsiębiorczości w Polsce w latach 1995-2014. Dotyczą one zarówno liczby podmiotów w określonych kategoriach, jak również powoływania zupełnie nowych form wsparcia rozwoju przedsiębiorczości i innowacyjności. Wzrost poziomu różnorodności form wsparcia rozwoju przedsiębiorczości można odnotować zasadniczo po 2000 roku, a od 2004 
roku - poszerzenie skali działalności, w postaci liczby tego typu podmiotów. Być może kluczem do wyjaśnienia takiej sytuacji było przystąpienie Polski do Unii Europejskiej i związana z tym możliwość pozyskania środków finansowych na aktywność w rzeczonym obszarze, a przede wszystkim zapotrzebowanie zgłaszane przez podmioty rynkowe (nowo powstające i prowadzące działalność) na różne formy wspierania ich funkcjonowania.

Zmiany w liczbie ośrodków, zwłaszcza w krótkim horyzoncie czasowym, są jednak trudno uchwytne, ze względu na łatwość zarówno ich powoływania, przekształcania, wykazywania filii czy likwidacji. Jeszcze trudniejszym jest zadanie ustalenia, czy dany ośrodek faktycznie działa, czy też nie, a działalność szeregu ośrodków afiliowanych przy instytucjach o innych celach statutowych (szkoły wyższe, instytuty badawcze, izby i cechy) posiada doraźny charakter (od projektu do projektu) i bywa wygaszana lub aktywowana w zależności od uzyskania lub nie zewnętrznego finansowania (Mażewska 2015, s. 11).

\section{Podsumowanie}

Przedsiębiorczość, jako proces tworzenia wartości, jest ściśle związana, zwłaszcza w wymiarze europejskim, z osobą przedsiębiorcy - jego osobowością, zachowaniem i profilem charakterologicznym. Selekcja pomysłów i podejmowane przez przedsiębiorców decyzje podlegają materializacji, czego przejawem stał się rosnący udział sektora MŚP w strukturze podmiotów gospodarczych. Innowacyjność, obok przedsiębiorczości, należy traktować jako współzależne, odrębne czynniki rozwoju podmiotów gospodarczych, regionów, systemów gospodarek krajowych.

Wyniki międzynarodowego badania GEM określają duży udział polskich przedsiębiorców jako osób dobrze przygotowanych do prowadzenia działalności gospodarczej (posiadających zdolności przedsiębiorcze), a jednocześnie dostrzegających szanse poprawy standardu życia poprzez własną aktywność w tym wymiarze. Przekonaniu o wysokich umiejętnościach przedsiębiorczych Polaków towarzyszy niska ocena dostepności szans na rozpoczęcie własnej działalności gospodarczej.

Uwzględniając fazy rozwoju gospodarczego danego kraju ukierunkowane na przedsiębiorczość i innowacyjność, zmianie podlega współczesna rola państwa w zakresie wspierania przedsiębiorczości i wzrostu gospodarczego. Podejmowane na poziomie administracji publicznej w ramach polityki ekonomicznej i społecznej działania interwencyjne o prorozwojowym charakterze powinny tworzyć spójny system wsparcia zarówno z punktu widzenia liczby instytucji, jak i merytorycznego zakresu ich aktywności. Brak uniwersalnego modelu takiego systemu stanowi o poszukiwaniach odpowiedniej struktury podmiotowej tych instytucji oraz ich zakresu zadaniowego, która na przestrzeni minionych lat przemian systemowych w Polsce nie tylko powstała, ale także ulegała pewnym zmianom. Zmiany o charakterze strukturalnym $\mathrm{w}$ otoczeniu przedsiębiorstw powinny pozwalać zarówno na kreowanie nowych rozwiązań, jak i dyfuzję już sprawdzonych sposobów, przede wszystkim w aspekcie przedsiębiorczości innowacyjnej.

W populacji ośrodków innowacji i przedsiębiorczości wspierających działania przedsiębiorców wykazywana jest (poza okresem 1998-2000) tendencja wzrostowa 
aż do 2012 roku. Kolejne lata 2013-2014 przyniosły jednak ograniczenie tego typu aktywności, zwłaszcza w formie akademickich inkubatorów przedsiębiorczości, centrów transferu technologii oraz ośrodków szkoleniowo--doradczych. Jednocześnie należy odnotować zwiększoną aktywność w zakresie tworzenia funduszy kapitału zalążkowego, funduszy pożyczkowych i poręczeń kredytowych, a także wyróżnienie nowej kategorii instytucji wsparcia - centrum innowacji, która odnosi się do wąskiego, aplikacyjnego rozumienia przedsiębiorczości - przedsiębiorczości innowacyjnej. Staje się to sygnałem do monitorowania nie tylko stanu (liczby) instytucji pomagających przedsiębiorcom, ich rzeczywistej aktywności, przekształcania form i zakresu dotychczasowej działalności, ale przede wszystkim możliwości realnego wsparcia postaw i zdolności przedsiębiorczych Polaków w formie udostępniania źródeł finansowania ich innowacyjności.

\section{Literatura}

1. Baumol W. (2010), The Microtheory of the Innovative Entrepreneurship, Princeton University Press, NJ and Oxford, Princeton.

2. Bąkowski A., Mażewska M. (red.) (2012), Ośrodki innowacji i przedsiębiorczości w Polsce. Raport 2012, PARP, Warszawa.

3. Bosma N., Wennekers S., Amorós J.E. 2012, Global Entrepreneurship Monitor 2011. Extended Report: Entrepreneurs and Entrepreneurial Employees Across the Globe, London Business School, London.

4. Cieślik J. (2015), Polska przedsiębiorczość - bilans 25 lat transformacji, „Alert" nr 1/2015/CP/ALK, Centrum Przedsiębiorczości Akademii Leona Koźmińskiego, Warszawa.

5. Cieślik J. (2010), Przedsiębiorczość dla ambitnych, Wydawnictwa Akademickie i Profesjonalne, Warszawa.

6. Cieślik J. (2014), Przedsiębiorczość, polityka, rozwój, Wydawnictwo Akademickie Sedno, Warszawa.

7. Cieślik J., Łopaciński M. (2014), Barometr Przedsiębiorczości jako narzędzie pomiaru krótkookresowych zmian w poziomie aktywności przedsiębiorczej, „Puls Biznesu”, 31 lipca.

8. Drucker P. (1992), Innowacje i przedsiębiorczość, PWE, Warszawa.

9. Glinka B., Gudkova S. (2011), Przedsiębiorczość, Wolters Kluwer, Warszawa.

10. Hernik D. (2015), Innowacje - skuteczna droga rozwoju, Portal Innowacji: www.pi.gov.pl/PARP/CHAPTER_8 6197. asp?soid=4 E5F15E9B6AF4864BFC8B6C5A993 02C8 (dostęp: 04.04.2016).

11. Kornai J. (2010), Innovation and Dynamism. Interaction between Systems and Technical Progress, "Economics of Transition", Vol. 18(4).

12. Kornai J. (2009), Innowacje i dynamika. Zależności pomiędzy systemami a postępem technologicznym, „Zarządzanie Publiczne”, nr 4(10).

13. Kozarkiewicz A. (2010), Wspótczesne trendy w innowacyjności $-w$ kierunku otwartych innowacji, „Przegląd Organizacji”, nr 5.

14. Kwiatkowski S. (2000), Przedsiębiorczość intelektualna, Wydawnictwo Naukowe PWN, Warszawa.

15. Łapiński J., Nieć M., Rzeźnik G., Węcławska D., (2015), Przedsiębiorczość i perspektywy rozwojowe sektora MSP $w$ Polsce, [w:] Tarnawa A., Zadura-Lichota P. (red.), Raport o stanie sektora matych $i$ średnich przedsiębiorstw $w$ Polsce $w$ latach 2013-2014, PARP Warszawa. 
16. Matusiak K.B. (2010), Budowa powiazań nauki z biznesem w gospodarce opartej na wiedzy. Rola i miejsce uniwersytetu $w$ procesach innowacyjnych, Oficyna Wydawnicza SGH, Warszawa.

17. Matusiak K.B. (2006), Rozwój systemów wsparcia przedsiębiorczości. Przesłanki, polityka i instytucje, Instytut Eksploatacji, Radom-Łódź

18. Matusiak K.B. (red.) (2011), Innowacje i transfer technologii. Stownik pojęć, PARP, Warszawa.

19. Matusiak K.B., Mażewska M., Banisch R. (2011), Budowa Skutecznego Otoczenia Innowacyjnego Biznesu w Polsce. Cele i założenia Inicjatywy Polskiej Agencji Rozwoju Przedsiębiorczości, PARP, Warszawa-Gdańsk-Poznań.

20. Mażewska M. (2015), Infrastruktura otoczenia biznesu w Polsce, [w:] Bąkowski A., Mażewska M. (red.), Ośrodki innowacji i przedsiębiorczości w Polsce. Raport 2014, Stowarzyszenie Organizatorów Ośrodków Innowacji i Przedsiębiorczości w Polsce, Poznań-Warszawa.

21. Okoń-Horodyńska E., Pangsy-Kania S. (red.) (2007), Innowacyjność w budowaniu gospodarki wiedzy w Polsce, Instytut Wiedzy i Innowacyjności, Warszawa.

22. Polska 2013. Global Entrepreneurship Monitor Polska. Raport z badań 2013 (2014), PARP, Warszawa.

23. Schutte N., Barkhuizen N. (2014), Factors Affecting Entrepreneurial and Economic Growth The Namibian Case, Proceedings of 26th International Business Research Conference, Imperial College, London.

24. Shane S. (2003), A General Theory of Entrepreneurship: The Individual-Opportunity Nexus, Edward Elgar Publishing, Northampton.

25. Singer S., Amorós J.E., Moska Arreola D. (2015), Global Entrepreneurship Monitor 2014 Global Report, Global Entrepreneurship Research Association, London Business School, London.

26. Stawasz E. (2011), Polityka innowacyjna wobec MSP, [w:] Niedzielski P., Stanisławski R., Stawasz E. (red.), Polityka innowacyjna państwa wobec sektora matych i średnich przedsiebiorstw w Polsce - analiza uwarunkowań i ocena realizacji, Zeszyty Naukowe Uniwersytetu Szczecińskiego, nr 654, Szczecin

27. Targalski J. (2006), Innowacyjność - przyczyna i skutek przedsiębiorczości, „Zeszyty Naukowe Akademii Ekonomicznej w Krakowie", nr 730.

28. Tarnawa A., Zadura-Lichota P. (red.) (2015), Raport o stanie sektora matych i średnich przedsiebiorstw $w$ Polsce $w$ latach 2013-2014, PARP, Warszawa.

29. Timmons J.A. (1999), New Venture Creation: Entrepreneurship for the 21st Century, Irwin/McGraw-Hill, Boston.

30. Wach K. (2015), Wzorce internacjonalizacji polskich matych i średnich przedsiebiorstw: synteza wyników ankietowych badań eksploracyjnych, [w:] Tarnawa A., Zadura-Lichota P. (red.), Raport o stanie sektora matych $i$ średnich przedsiębiorstw $w$ Polsce $w$ latach 2013-2014, PARP, Warszawa.

31. Wierżyński W., Innowacyjność w czasie kryzysu, Portal Innowacji, www.pi.gov.p1/parp/ chapter_861 96.asp?soid=6C3AF77EA6FC4BCE8A6553E491A6DE8B (dostepp: 04.04.2016).

32. Zbierowski P., Węcławska D., Tarnawa A., Zadura-Lichota P., Bratnicki M. (2012), GEM Polska. Raport z badania Global Entrepreneurship Monitor - Polska 2011, PARP, Warsza- 


\section{ENTREPRENEURIAL BEHAVIOURS OF THE PEOPLE OF POLAND AND FORMS OF SUPPORTING OF ENTREPRENEURSHIP DEVELOPMENT IN POLAND}

Abstract: Systemic socio-economic transformations initiated in Poland after 1989 reflected in change of attitudes of the Poles related to entrepreneurship and innovation. Lack of own experience and kind of experimenting in this regard became an opportunity to launch various forms of support for activities in this type and to make use of them in socio-economic growth of the region and country. Effectiveness of their launch requires, though, building coherent entrepreneurship policy, innovation and development of SME sector based on activity of public administration, business sector and also education and science sector.

In the study was used analysis of results of international research conducted by Global Entrepreneurship Monitor (GEM), Polish Agency for Enterprise Development [Polska Agencja Rozwoju Przedsiębiorczości] and Polish Business and Innovation Centers Association in Poland [Stowarzyszenie Organizatorów Ośrodków Innowacji i Przedsiębiorczości w Polsce].

The aim of the paper is to diagnose broadly defined predispositions of the Poles in context of increase in the amount and scope of support forms for their entrepreneurship and innovation.

Keywords: development, entrepreneurship, innovation, support system 